\title{
The Archaeology of Industrialisation and the Textile Industry: the Example of Manchester and the South-western Pennine Uplands During the 18th Century (Part 1)
}

\author{
Michael Nevell
}

Between the early 18th century and the mid-19th century the north-west of England was turned from a relatively impoverished backwater to one of the major industrialisation zones in the world. This is thus a key region for understanding the archaeology of the early stages of industrialisation. The area around Manchester was at the heart of this process, which was driven in this region by the mechanisation of the textile industry. The archaeological remains of this industrial transition are not only very extensive but also comparatively early when considered against the classic period of the Industrial Revolution; the decades either side of 1800. This paper discusses this early evidence and the results of a wide-ranging regional survey looking at the archaeology of industrialisation within the textile industry and the role of local tenant farmers in promoting industry in and around Manchester during the 18th century. It highlights a number of key sources of evidence for this period and suggests some future directions for archaeological research into the early industrialisation of this important region. ${ }^{1}$ The second part will be published in Industrial Archaeology Review $X X X .2$.

\section{INTRODUCTION}

The topography of the Manchester area is characterised by uplands to the south-east, east and north. In these uplands areas are the streams that feed the major rivers of the Mersey Basin; the Etherow, Goyt, Irwell, Mersey, Medlock, and Roch (Figure 1). These streams and their valleys give the uplands around Manchester a characteristic undulating feel, with steeply-sided valleys surrounded by tall but rounded hills running mainly north-east to south-west. In the 18 th century and first half of the 19th century these valleys were some of the most dynamic and industrialised landscapes in Britain, being filled with hundreds of vernacular workshops and water-powered cotton and woollen mills leased and built by the capital-rich and independently-minded tenantry of the region. In north-west England these valleys were, literally and metaphorically, the headwaters of the Industrial Revolution.

\section{The Rise of Domestic TeXtile Manufacture Around Manchester}

During the 16 th and 17 th centuries the scattered, rural population of the uplands around Manchester lived in isolated family farms. The economy was largely pastoral with sheep, cattle, and oats reared and grown mostly for the immediate domestic needs of the family. However, from the early 17 th century onwards this subsistence farming was increasingly supplemented by the domestic spinning and weaving of flax and wool. A key change in south-east Lancashire was the introduction of cotton in the first half of the 17th century, which by the later 17 th century was being woven as a weft with a flax warp to make fustian, a hard-wearing cloth designed for the market rather than the home. ${ }^{2}$

This significant change in the domestic work pattern is reflected in the probate evidence of the 17 th and early 18 th centuries. From 1640 such evidence from upland parishes such as Ashton-under-Lyne and Mottram-in-Longdendale includes increasing numbers of items related to textile production such as cotton, flax, and wool yarn; raw wool and linen cloth; kersey pieces and blankets; spinning wheels, woollen wheels, looms, gears, and cards; tenter bars and boards, shears and shearboards, presses, and papers. Joyce Powell's study of the wills and inventories of Mottram in the period 1570 to 1680 , for instance, shows that 67 inventories, which is $29 \%$ of the total number of inventories surviving from this period in the parish, contained 'some item of textile equipment, varying from the single pair of cards in a carpenter's inventory of 1647, to two woollen looms, tenters and wheels of a clothworker, priced, with some joinery tools, at $£ 613 \mathrm{~s} \mathrm{4d}$ '. Most of these references occur after 1660 , with 24 of the 35 instances of spinning wheels coming from the period $1660-1680 .^{3}$

John Stobart's important study of the probate evidence for Cheshire and that part of Lancashire south of the Ribble between 1700 and 1760 indicates that during this period textiles were the most important element of the local economy in both many of the 


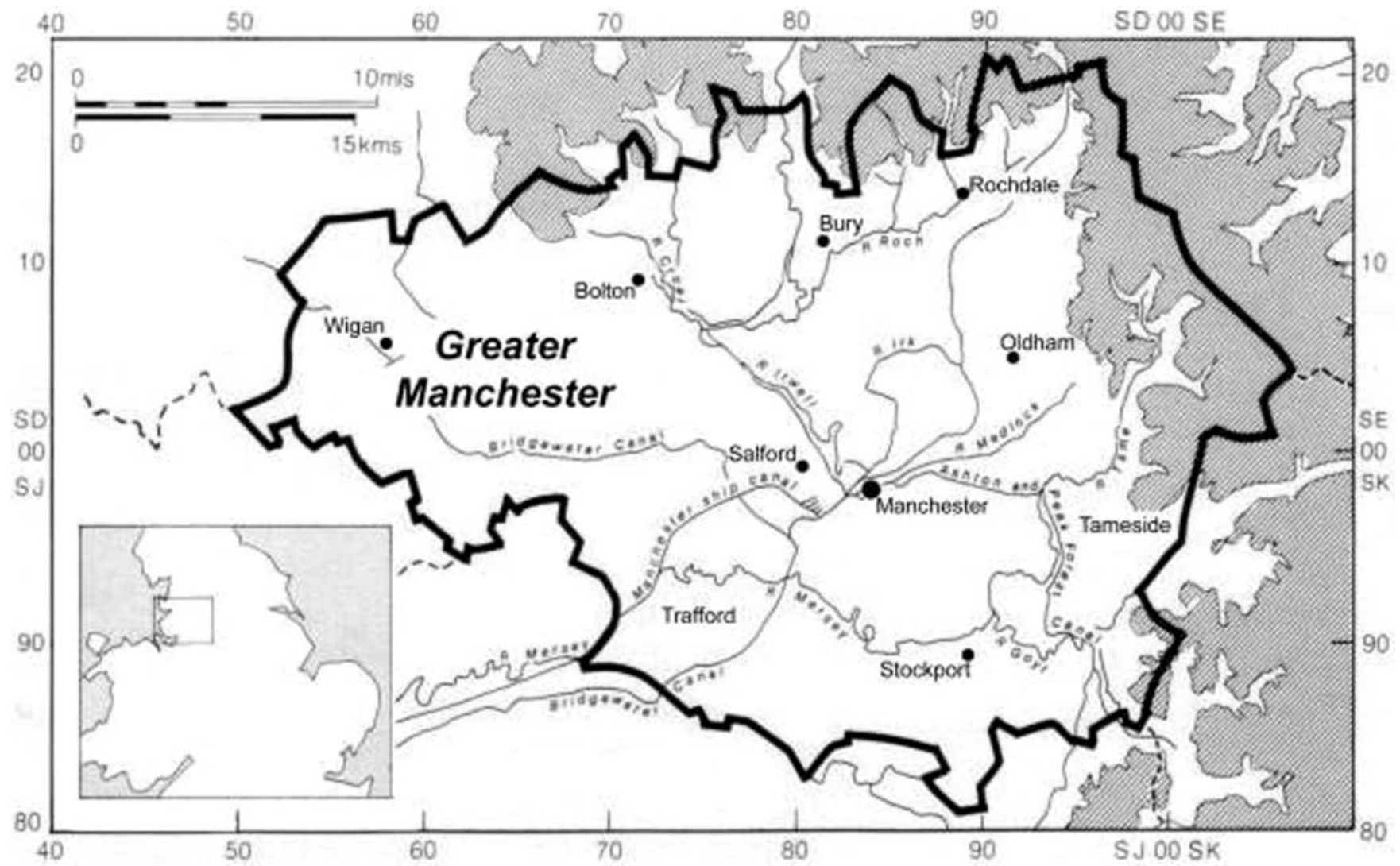

Figure 1.

Map of the Greater Manchester area (after Williams with Farnie, 1992). upland valley communities and in the local urban market centres of south-east Lancashire. ${ }^{4}$ This expanding industry had distinct regions specialising in the home-based production of textiles such as fustians (Bolton, Bury, and Blackburn), smallwares (Manchester), silks (Stockport and Macclesfield) and woollens (Burnley, Colne, Haslingden, Rochdale, and Stalybridge).

The archaeological visibility of this growth in the textile trade and its industrialisation around Manchester does not become obvious until the 18 th century when the capital generated by this domestic-based industry began to be used to build two new types of manufacturing site; the vernacular workshop and the textile mill.

\section{The Vernacular WorkshoP}

The earliest of these new monument types was the vernacular workshop, or weaver's cottage, as they are more commonly known in this region (Figure 2). The wills and inventories of parishes such as Ashton-under-Lyne, Bolton, Bury, Mottram-in-Longdendale, Rochdale, and Saddleworth ${ }^{5}$ often refer to 'shops', meaning workshops, being used for metal, shoe, textile, or some other form of domestic industry by tenant farmers from in the late 17 th century. By the first half of the 18th century many farm houses had either a dedicated room for domestic textile manufacture or an additional one- or two-storey workshop range. In the
Saddleworth area more than 21 two-storey workshops are known from the 18th century, some of which, like the two-storey house and workshop at Oakdene Cottage, Deanhead, Saddleworth, can be accurately dated by the documentary evidence. ${ }^{6}$ However, from this period a separate and dedicated three-storey textile workshop began to be built in the valleys around Manchester, and it was this type of domestic workshop which predominated across much of Greater Manchester. One of the earliest examples to survive in the region can be found on School Lane in Cheadle, Stockport (SJ 854 872). Now known as South View, but originally called The Croft, it is a three-storey, double-depth cottage built in brick. It was sold by the Tatton estate for $£ 23$ 10 s., along with the plot of land it stood on, in 1721 to a local farmer, Samuel Smith, who appears to have had the property built a few years earlier. ${ }^{7}$ Its original function is unclear, although it seems highly likely it was built for renting out to textile spinners and weavers. It had all the elements that came to typify the weavers' cottages of south-east Lancashire and north-east Cheshire; a two-room deep, three-storey, in this case brick structure with a central staircase and doorway, and originally ten multi-light arched windows to each floor at both the front and back, and a taking-in door in the gable on the top floor.

Such workshops, along with the one- and two-storey farmhouse workshop additions, were a physical expression of the growth of 


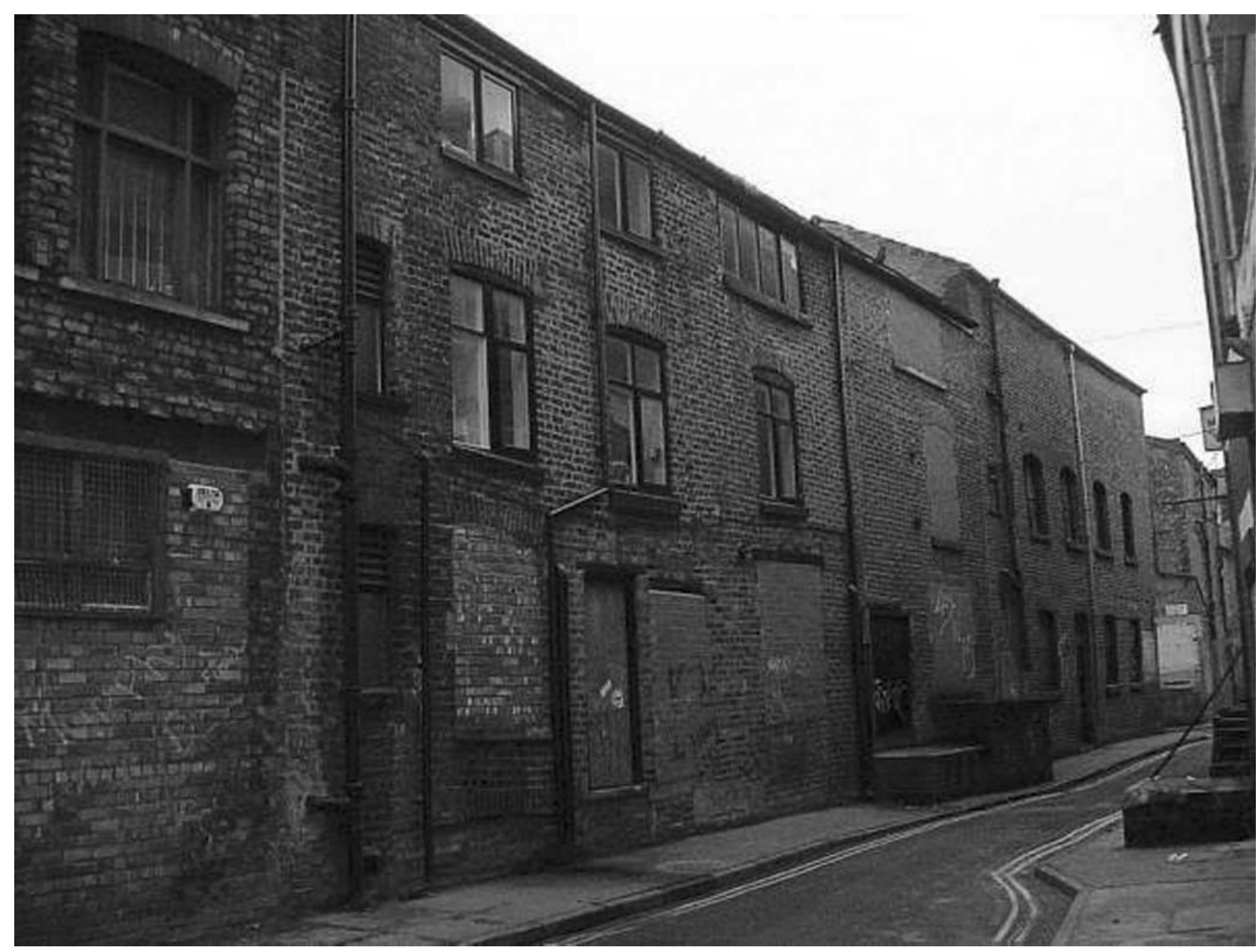

the textile industry during the 18th century. They reflect two different ways of organising production. First, artisan production which was the domestic manufacture of textiles by independent, skilled, craftsmen. In these households a significant proportion of the total family income was derived from the manufacture or processing of such goods for sale. ${ }^{8}$ Such artisan production was very common in the woollen producing areas of West Yorkshire and in the uplands of southeast Lancashire around Rochdale, Littleborough, and Oldham. Secondly, merchant capital production, whereby the preparation, manufacture, and finishing as well as the marketing of textiles was organised by a few clothiers but carried out by many workers on a commission or order basis. ${ }^{9}$ Within the Lancashire cotton industry this was usually done on the 'putting-out' system, where the entrepreneur clothier raised the capital to buy the raw material and then organised production by putting-out parts of it to spinners, weavers, and finishers working at home. In other words this was dispersed production under a central control.

Several hundred of these three-storey vernacular workshops were built, and still survive, in south-east Lancashire and northeast Cheshire from the 18th and early 19th centuries. Of these 110 examples are now listed buildings, with notable concentrations in Atherton, Bolton, Eccles, Horwich, Littleborough, Manchester, Marple, Milnrow, Oldham, and Saddleworth. The largest concentrations can found in the centre of Manchester, with 29 listed workshops, and in the rural upland district of Saddleworth with 43 listed workshops, although the numbers that survive in these areas are much higher; in Manchester's case around 50 such buildings are known. ${ }^{10}$ This high level of survival in both urban and rural locations indicates that domestic production was not confined to the upland valleys around Manchester and therefore models which suggest a clear split between rural textile production and urban market centres are likely to be over-simplistic.

One of the best studied areas of weavers' cottages is the Tameside area, east of Manchester. Here in the foothills of the west Pennines can be found at least 77 extant vernacular workshops (Figure 3), although only 13 are listed buildings, with notable concentrations in the Longdendale valley
Figure 2.

Back Turner Street in Manchester showing vernacular workshops. 

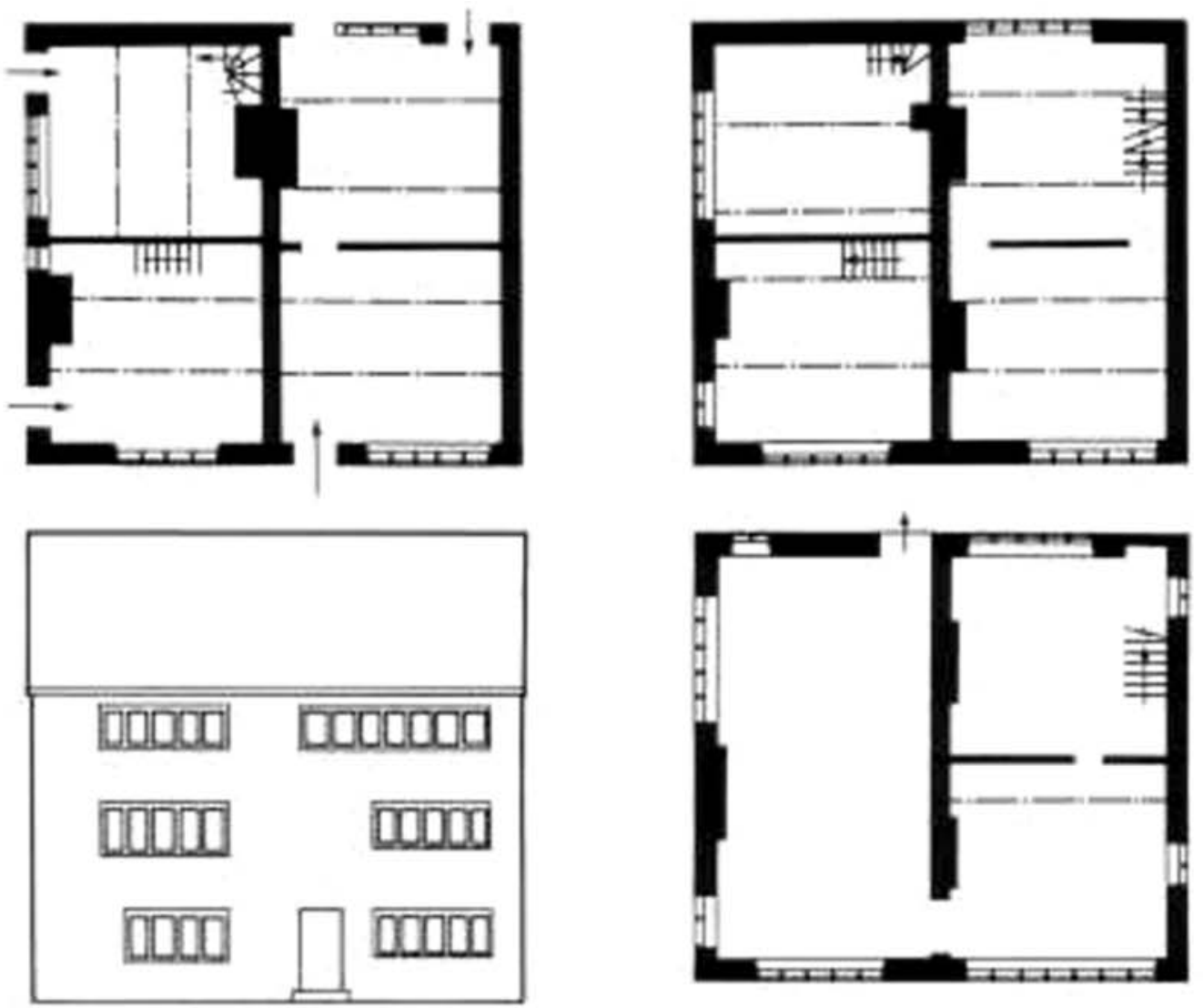

Figure 3.

Tameside weavers'

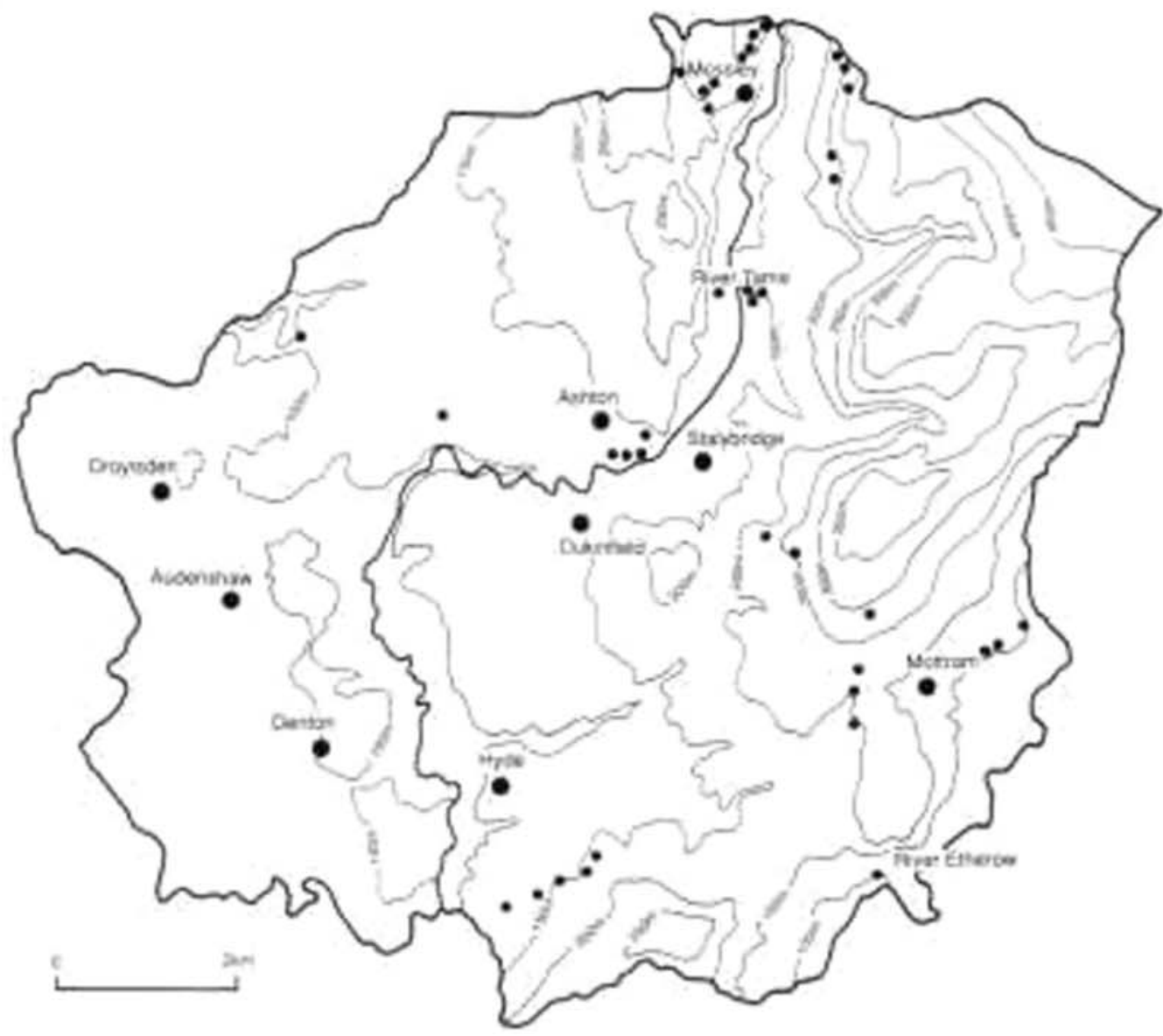


(Hollingworth, Hyde, and Mottram) and the middle reaches of the Tame valley (Mossley and Staley). Those examples with datestones range from a pair of double-depth cottages built at Wednesough Green in Hollingworth in 1772 to a row of four, double-depth, threestorey cottages on Staley Road in Mossley dated to 1802 , though the date range is undoubtedly wider than this. ${ }^{11}$ Amongst the pairs and rows of weavers' cottages was a distinctive group of three-storey, often singledepth, textile workshops built as additions to farmhouses and which appear to have been an integral part of these farmsteads. In Tameside at least a dozen examples are known in the Pennine foothills, at for instance Moorgate Farm in Staley, The Fold in the Carrbrook Valley, and at Wrigley Fold in Matley. These examples were all built by tenant farmers in the 18 th century. ${ }^{12}$

It is difficult from the physical evidence or these workshops alone to identify archaeologically which form of production was taking place in any particular part of the uplands around Manchester during the 18th century; not just whether these workshops contained cotton, fustian, linen or wool production, but also whether they were associated with artisan of merchant capital production. However, by comparing the documentary evidence for the vernacular workshop with the physical evidence for these buildings in an area such as Tameside, or the equally well studied district of Saddleworth in Oldham, it is possible to suggest a very broad correlation between rows of workshop dwellings which appear to have been sponsored by merchant capital production, and those workshops (both the one-, two- and three-storey varieties) associated with farmsteads which appear to reflect artisan production.

At Wrigley Fold in Matley, near Mottram, a three-storey, two-room deep, vernacular workshop was built during the late 18th century by the Wrigley family, whose probate evidence indicates were both tenant farmers and cotton weavers involved in artisan production from the early 18 th century to the early 19th century. The workshop was added at the north-eastern end of the 17th-century farmhouse and was accessed from that farmhouse internally on the ground floor. Externally, the workshop had the characteristic long rows of multi-light windows on each floor in the north-western and south-eastern elevations.

A good example of the merchant capital type of vernacular workshop built in Tameside is provided by Summerbottom in Broadbottom (Figure 4). These workshops were built by the textile manufacturer and tenant John Swindells, who was spinning cotton in the adjacent Hodge Mill on the River Etherow. Summerbottom is a terrace of six cottages erected in 1790, with later additions of the mid19th century at one end. ${ }^{13}$ The terrace, which is built into the valley side, is of three storeys.

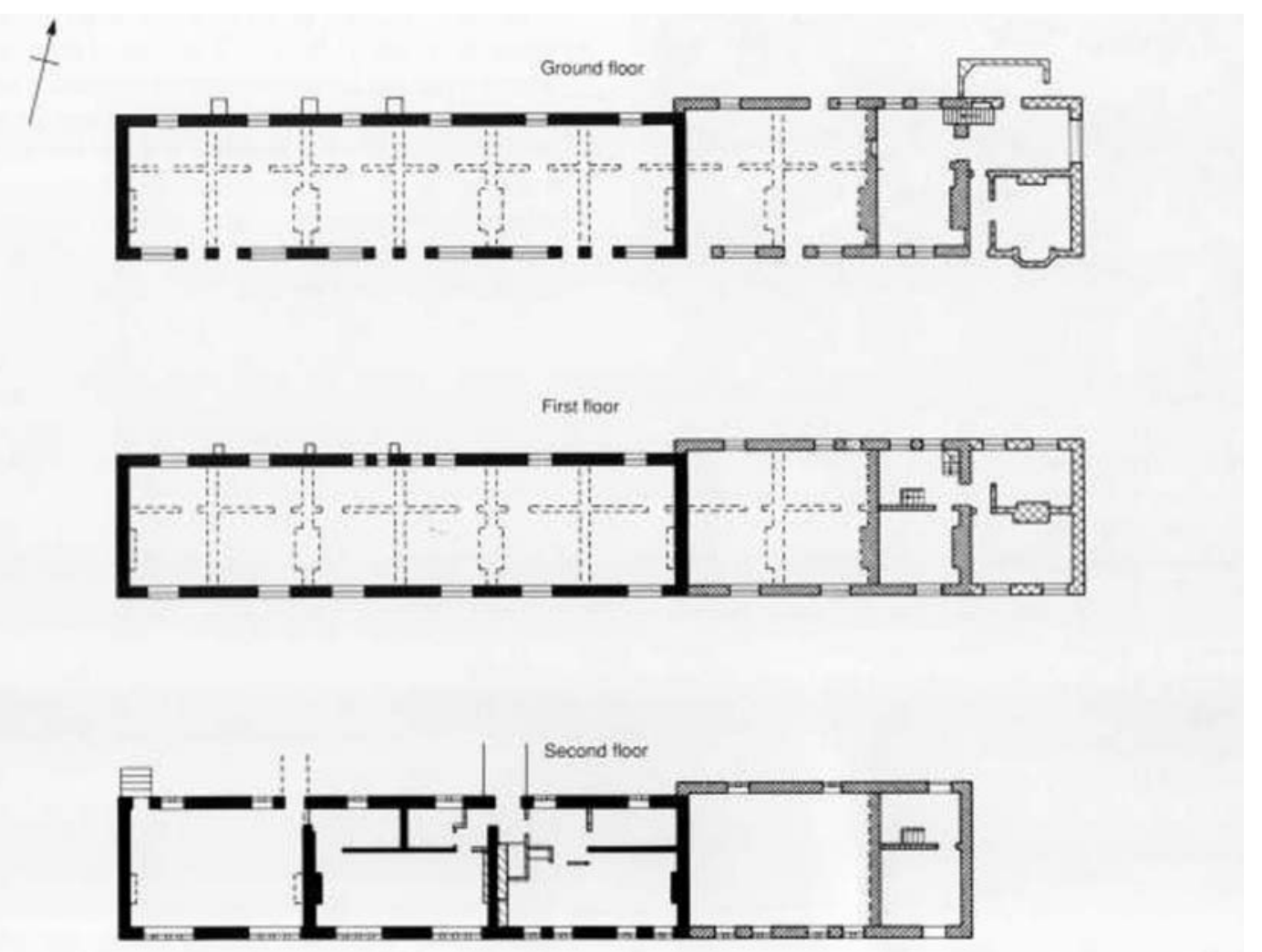


Figure $4 b$. Summerbottom rear taking-in door.

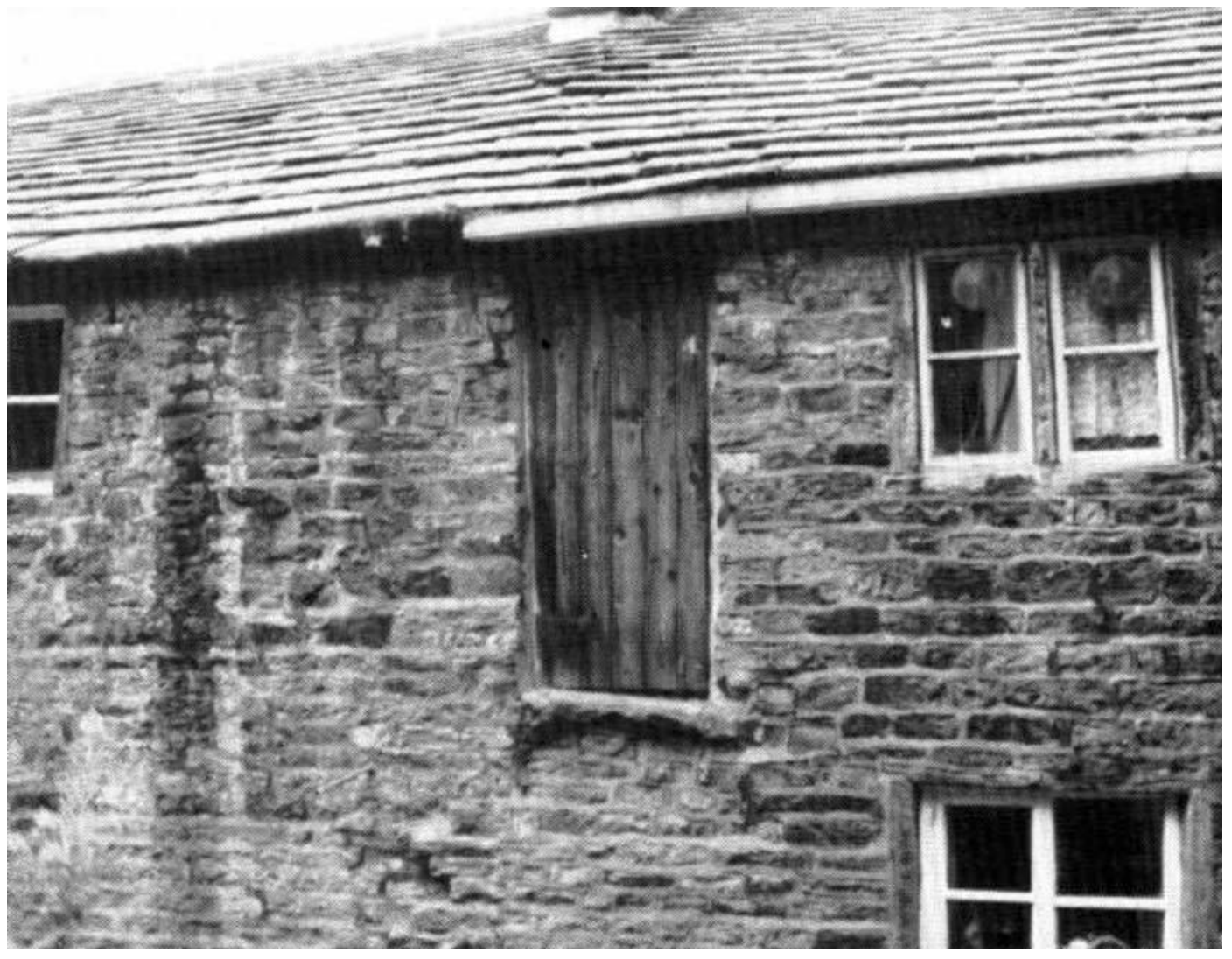

The ground- and first-floor levels consisted of two-storey cottages, a single room wide and possibly originally only a single room deep, heated by a fireplace in the side wall. The second floor comprised a loomshop that was divided into three intercommunicating rooms. The front of the terrace is south facing and at second-floor level contains several multi-light mullioned windows. Access into the loomshop was provided not from the cottages but via three entrances at the rear of the terrace. Because of the slope in the hillside, these are virtually at ground-floor level. One is now approached by steps, another by a stone bridge, and a bridge may also have provided access to the third. Such a large workshop, completely separated from the domestic quarters below, allowed the textile manufacturer direct personal control of the quality and quantity of the finished product, with his handloom weavers also being his sub-tenants.

Thus, of the 77 extant three-storey, vernacular workshops built in Tameside during the 18 th and early 19th centuries, there are 28 examples of row workshops, many of which can by documentary evidence be associated with merchant capital production and 16 farmbased workshops all of which can be associated with artisan textile production by local tenant farmers. ${ }^{14}$ The remaining vernacular workshops in Tameside belong to either single or pairs of isolated weavers' cottages, the social context of which is more ambiguous, but for which artisan production might be suspected.

\section{The Mill Types of the i 8Th Century}

Whether the weaver's cottage was a single pair, a farmstead workshop associated with artisan production, or a row associated with merchant capital production, they all represented an intermediate stage in the industrialisation of textiles (cotton, fustian, linen and wool) in the uplands around Manchester. The rest of this paper is concerned with the archaeological remains of the next stage in the mechanisation of the textile industry (primarily for cotton and wool) and the second type of new monument built around Manchester in this period; the textile mill.

Early upland water-powered textile mills form an important but under-studied part of the textile industry of north-west England. Though less numerous than the better known and better studied steam-powered textile mill of the 19th century, the impact of the hundreds of cotton and woollen water-powered factories established in the upland valleys of the region, particularly to the north and east of Manchester during the 18th and early 19th centuries, was no less dramatic. Streams were dammed, reservoirs and weirs built, leats were cut or dug, and multi-storey factories erected in wild and remote country that in many cases had not seen any industry before the 18th century, and often had not witnessed such intensive human activity since the hunter-gathers of the Mesolithic roamed the Pennine uplands 6,000 years earlier. 
Particularly after 1769 much capital was spent by the emerging textile tenantry in a flurry of factory-building that is reflected in the archaeological record today. Tracing the location and development of these mill sites is not straight forward. ${ }^{15}$ Often these mills are dominated by the standing remains relating to the final phases of the textile site's activity, as at the Caplrina Print Works, which completely mask the earliest industrial phases of such sites. Sometimes archaeological investigation of the standing remains of a mill, such as Albion Mill in Hollingworth and Dry Mill in Mottram, or excavation of a long demolished site as at Carr Mill at Carrbrook or Moss Mill in Broadbottom can reveal the true 18th-century origins of such textile sites. Since 1992, when the book on the cotton spinning mills of Greater Manchester was published, ${ }^{16}$ there has been an upsurge in the number of archaeological surveys of mill buildings, 54 by the end of 2006, and in the excavation of mill sites, 24 by the end of 2006, in Greater Manchester, a significant number of which, 20 sites, have now been shown to have an 18th-century origin.

Such fieldwork is labour-intensive and time-consuming and often documentary evidence in the form of land tax returns, estate rentals, insurance records, newspaper adverts, and more rarely deeds, combined with map evidence and landscape analysis, can be used to show an 18th-century water-powered origin for what at first may appear to be an early 20th-century steam-powered mill site.

In the past, attempts to quantify the numbers of textile mills built in the market centres and uplands of south-east Lancashire and north-east Cheshire have been confined to the identification of the Arkwright mill type-site both as a water-powered cotton spinning mill from 1771 and as a waterpowered wool spinning mill from 1785 onwards. Analysis by John Chapman of a contemporary census of Arkwright patented mills from 1788 suggested 44 textile mill sites for Lancashire and 15 for Cheshire of which 17 were located in the Greater Manchester area, ${ }^{17}$ whilst a recently published study of Arkwright-type mills in the North-West, which also included an analysis of other contemporary documentary material such as newspaper adverts and deeds, suggested 36 such mills were built in and around Manchester. However, when this documentary approach is extended to all textile mill sites built in the 18th century the numbers rise considerably. Through such analysis at least 387 water- and steam-powered textile mills have been identified as operating in Greater Manchester (the old areas of south-east Lancashire and north-east Cheshire) between 1700 and 1800. These figures are themselves a substantial increase from the figure of 154 textile sites for Greater Manchester published in 2003 and reflect the growing archaeological and historical research in this area in recent years. ${ }^{18}$

Consequently, there is now a sufficiently large database to characterise the physical remains of the first generation of textile mills in the valleys around Manchester. The 387 18th-century textile sites identified in southeast Lancashire and north-east Cheshire (now known as Greater Manchester) can be divided into five types of mill structure (wool fulling, wool scribbling, silk, cotton spinning, and finishing).

\section{Fulling Mills}

The earliest water-powered textile mills in the Manchester region were for the fulling of woollen cloth. Woollen production was of particular importance in the Oldham, Rochdale, Saddleworth, and Tameside areas. By the 16th century Lancashire already had a well established textile industry whose two main staples were linens and woollens. In the later 17th century these older branches were largely replaced by the introduction and spread of cotton, at this period in the form of fustians. By 1700 woollen production was almost entirely confined to the eastern border of the county and in the Rochdale and Saddleworth districts woollen manufacturers retained a monopoly as late as the early 19 th century. ${ }^{19}$

Fulling was the first process within the textile industry to which water power was applied. It had two purposes; to remove natural oil and grease from woven cloth, a necessary step before dyeing could be carried out, and to tighten and thicken the fabric. In the fulling mill this was achieved by pounding the cloth with water-powered hammers, or stocks, while soaking it in water mixed with a cleaning agent (for which fuller's earth and stale urine were used). Before the application of water power to the process, fulling was carried out by treading, or walking, the cloth, which led to fulling mills also being known as walk mills.

Of the 36 fulling mills recorded in Greater Manchester during the 18 th century, 31 were built between 1750 and 1800 , mostly after 1780. These new fulling mills were concentrated in Littleborough, Rochdale, and Saddleworth, though the Mossley area of Tameside had three such mills by 1800 . The upsurge in the construction of fulling mills in the later 18th century probably reflects the increasing demand for all forms of textiles during this period. Few of these 18th-century fulling mills survive and none is complete, one of the best examples being the five-storey, stone-built, Crimble Mill at Bamford in Rochdale. This was built as a fulling mill in 1761, but rebuilt as a cotton spinning mill 
around 1829 and further altered in 1886 , by which date it had returned to wool production although it was spinning wool rather than fulling. Such a pattern of site development and change of use was common for many 18th-century mills around Manchester and is one of the reasons why so little standing fabric from 18th-century textile mills survives.

\section{Woollen Scribbling Mills}

After fulling, the next stage of woollen manufacture to be powered was scribbling, the equivalent of carding in the cotton industry. Scribbling was the preparation of wool for spinning by separating the tangled mass of the fibres of the raw wool and then brushing them parallel. This was done between the wire combs of card cloth that removed short fibres, seeds, and seed cases, and brought the majority of fibres more or less parallel with each other to form a loose, untwisted wool shank known as a sliver. Originally done by hand using thistles on boards, the first carding machine was patented in 1748 by Daniel Bourne, but this was a somewhat inefficient hand-powered affair. Once spinning machines had been invented, scribbling and carding became a serious bottleneck in the production of yarn, a problem which was only solved when Richard Arkwright patented a water-powered rotary carding machine in 1775. This fed the raw cotton or wool between a series of cloth-covered card rollers spaced around a large drum also covered in card cloth. ${ }^{20}$ Consequently, scribbling or carding mills dedicated to this single process became very common in the last quarter of the 18th century. In Lancashire such factories were known as scribbling mills, even though it was a term usually used only in the woollen industry. This makes the differentiation between cotton and woollen carding mills difficult in the region. ${ }^{21}$

Between 1775 and 180053 mills containing carding machines or 'engines' were established in Oldham, Rochdale, Saddleworth, and Tameside. One of the few surviving examples is Shaw Mill in Delph (SD 986 079). ${ }^{22}$ Erected in 1782, this is a hammerdressed stone-built three-storey structure with a centrally placed undershot waterwheel. The exterior elevations are very distinctive with a row of 12-light windows on the first and second floors at the front. The rear elevation retains a blocked arched opening for the head race, three- and four-light ground-floor windows, two five-light windows on the first floor, and on the second floor a long 12-light window. Internally, each floor comprised a single room with the ceilings supported by single-span beams. Externally and internally this arrangement was very reminiscent of the vernacular workshop, or weavers' cottages, of the area.

\section{Silk Mills}

Silk mills formed a small but significant part of the new factory-based textile industry during the 18th century, especially in eastern Cheshire. The first successful silk factory in Britain was Lombe's silk mill in Derby. Built in 1721 it was a five-storeyed building $33.5 \mathrm{~m}$ long by $12 \mathrm{~m}$ wide and $17 \mathrm{~m}$ high, containing Italian-style silk throwing machinery copied by Lombe in Italy, and was driven by an undershot water wheel $7 \mathrm{~m}$ in diameter. ${ }^{23}$ Lombe's silk machinery was covered by a patent that did not expire until 1732. Of the seven silk mills erected in England between 1732 and 1769 and housing Italian-style throwing machinery of the Lombe type four were in Cheshire; Logwood Mill in Stockport built in 1732, Button Mill in Macclesfield in 1744, Old Mill in Congleton built in 1753, and an unknown Macclesfield mill, probably Townley Street, which was erected by $1769 .^{24}$

By the end of the century there were nine silk mills in Stockport and one in Manchester. Unfortunately no extant examples survive in the Manchester area, although there are a number of 18th-century silk mills still standing in Macclesfield, Cheshire. Whilst the silk mill was the least common textile mill building type in the North-West during the 18th century, it was a vital step in the development of the industrial factory since it had the essential elements characteristic of all such later buildings: a well-lit, uncluttered floor area large enough for the efficient accommodation of processes, and adequate accommodation for ancillary processes and storage. ${ }^{25}$

\section{Cotton Spinning Mills}

The water-powered cotton spinning mill was the most common of all the mill building types erected during the 18th century. These housed the first part of the cotton manufacturing process to be mechanised.

The earliest practical machine for cotton spinning (that is, the drawing out and twisting of fibres to form a long thread) was invented by James Hargreaves in 1764 and was known as the spinning jenny. This was a multi-spindle machine that drafted and twisted the cotton in one stage and wound it onto a spindle in a second stage. The whole process was handdriven via a wheel on a machine that initially had eight spindles, but in its most developed form in the early 19th century had as many as $120 .{ }^{26}$ The yarn produced was soft and thick, rather than having a consistently hard twist, but for the cotton industry was ideal for use as weft, which is probably why the hand-powered jenny remained in popular use as late as the patenting of the self-acting mule in $1830 .{ }^{27}$ Two other types of cotton spinning machinery 
were developed in the late 18th century. The most influential was Richard Arkwright's water-frame that he initially patented in 1769 . His 1769 prototype engine, which was horsedriven, could spin four threads at once using drafting rollers to stretch the loose roving and a flyer to twist the drawn-out roving into a thread that was then wound onto a bobbin..$^{28}$ However, it was not until 1771 that he first applied water-power to the frame at his new mill in Cromford. A second patent in 1775 encompassed a variety of preparatory machines to serve the water frame and included a continuous carding engine for producing slivers; a draw frame where four slivers were combined and stretched to form a single largely even roving; and a lantern frame that converted the sliver into roving, a lightly twisted rope of fibres strong enough to be used on the water frame, which by this date could accommodate 96 spindles. The resultant wiry yarn was ideal for use as both warp and weft. By 1784 the water frame had been adapted to spin wool into worsted yarn. ${ }^{29}$

Arkwright's second patent of 1775 allowed him to market a complete manufacturing system, including the mill building and the water-power system, as well as the preparation and spinning machinery, rather than just a single spinning machine. As a result Arkwright has been called the father of the factory system and of the industrial society which emerged in the following century.

The last of the mechanical cotton spinning machines to be invented in the 18th century was Samuel Crompton's spinning mule in 1779. This was a combination of the jenny and the water frame that used the bare spindle spinning of the former and the drafting rollers of the latter to produce a very fine, hardtwisted, yarn suitable for warps and able to match the fine muslin fabrics of India. ${ }^{30}$ Originally hand-powered with just 48 spindles, the mule was rapidly developed by mill owners (it was not patented by Crompton, much to his disadvantage) so that by 1790 mules with 150 spindles were common, and by 1800 a semi-automatic version held 400 spindles. This version of the mule was designed to be partially power-driven so that the movement of the carriage and the twisting, stretching, and drawing out of the yarn could be wateror steam-driven, although backing-off and winding still had to be done by hand. ${ }^{31}$

The new cotton mills of the post-1769 era, which housed these spinning machines, were essentially functional buildings, whose form was dictated primarily by the processes they were intended to contain. As the machines changed in size (from the spinning jenny to the water frame and then to the spinning mule) and as newly mechanised processes were added to the industry (such as the scrutcher, lap former, drawing frame, and lantern frame) so mill architecture changed. Archaeological and documentary evidence records at least 219 cotton spinning mills of various types built in and around Manchester between 1769 and 1800.

Most of the first generation 18th-century textile factories were built on a small scale. Jennies could be housed in existing buildings such as a barn, whilst corn mills could be adapted to take carding engines, water frames, or mules. This allowed many local tenant farmers to enter the cotton manufacturing business. A detailed survey of the textile mills of the Tameside area revealed that of the 274 textile mills established within the borough between 1763 and 1907, 67 were built before 1800 . One of the first textile buildings in the Tameside area reused the old corn mill on the River Tame at Ashton that was converted in 1773 to a print works and then in 1784 into a waterpowered cotton carding mill. ${ }^{32}$ The waterpowered cotton spinning factory known as Old Street Mill in Stalybridge was also established in an old corn mill on the River Tame, around 1790. Stalybridge's first mill was the 'Soot Poke' Mill which was established around 1776, possibly in an existing building next to a small stream running off Ridge Hill. Neddy Hall, the owner, appears to have been a local tenant farmer. His mill housed both a waterpowered carding engine and hand-powered jennies. ${ }^{33}$ Another early cotton mill that probably housed jennies was a barn converted for such use in Mottram. Wagstaffe's Factory, as it was known, was converted around 1786 by John Wagstaffe, a local tenant farmer, and probably housed horse-driven jennies. James Odgen's Mill on Crickets Lane in Ashton may also have been established in an old barn some years before $1800 .{ }^{34}$ The conversion of existing buildings for hand-powered mule spinning machines became common after 1785 when certain patent claims by Arkwright were rejected. According to the 19th-century local historian Edwin Butterworth in 1794 Ashton contained around 10 spinning rooms or small factories of this type, some supplemented by horse-driven carding machines ${ }^{35}$ but each employing no more than 10 or 20 people. These are, however, practically impossible to locate archaeologically, although documentary evidence has indicated the location of one ruinous example. This is a building known as Wagstaffe's Factory (SJ 9929 9556) which a local Mottram tenant farmer, John Wagstaffe, had converted from a barn into a horsepowered or hand-powered jenny mill in $1786 .^{36}$

Whilst the number of converted rooms and barns used for textile production is unknown, documentary and archaeological evidence indicates that at least 200 purpose-built cotton factories were erected in the hills to the north, east and south-east of Manchester between 
1769 and 1800. Most of these housed the new spinning machines; the jenny, the mule, and the water frame. The small scale of some of the earliest purpose-built factories is shown by the surviving example of Dry Mill in Mottram (SJ 9930 9556) which was built around 1796-1797 by John Wagstaffe as a cotton spinning mill of two storeys, $10 \mathrm{~m} \times 20 \mathrm{~m}$. Its name arose from the fact that it was not water-powered, and although the precise motive power is unclear, it was almost certainly horse-driven and probably contained jennies. ${ }^{37}$ The largest and most technically sophisticated 18th-century cotton spinning mill was the Arkwright-type factory which housed the water frame. The size of the water frame determined the width of the mill, since pairs of water frames were placed across the mill with the drive shaft running lengthways through their centres. With the addition of a gangway at the end of the frames such mills were usually $30 \mathrm{ft}(9 \mathrm{~m})$ in width and usually ranged in length between 70 and $120 \mathrm{ft}$ $(22 \mathrm{~m}-36 \mathrm{~m})$, although there were shorter and longer examples. Most of these mills had three or four storeys, though examples as tall as seven floors are known, as at New Lanark in southern Scotland. Waterwheels were positioned either in the middle or at the gable end of these mills and the large amount of water needed to turn the wheel meant that extensive leats and reservoirs were built. Precisely how many Arkwright-type mills were built in the North-West is unclear. A census of the mills published in 1788 records 39 in Lancashire and seven in Cheshire, but these figures were revised to 44 in Lancashire and 15 in Cheshire in 1982. The Lancashire figure was further revised in 2003 to 101 Arkwright-type mills. ${ }^{38}$ The current study has recorded 219 cotton spinning mills built in Greater Manchester during the 18th century, but less than a quarter of these were Arkwright-type mills.

Such mills required a substantial amount of capital to build, with $£ 3,000$ in the early 1780 s needed for a 1,000 spindle mill with a $10 \mathrm{hp}$ waterwheel, which appears to have been the smallest type, employing 100-200 operatives. ${ }^{39}$ An advertisement in the Manchester Mercury records an Arkwright-type mill in Hattersley up for auction that was built by a local tenant farmer called Ned Holt around 1788. It was $69 \mathrm{ft}$ by $18 \mathrm{ft}$ and three storeys high and appears to have cost $£ 1,000$ to build, bankrupting the tenant farmer in the process. ${ }^{40}$ The location of this mill has been subsequently lost. There are a few late 18th-century Arkwright-type mills surviving in Greater Manchester. In Bolton the four-storey, stone-built, St Helena Mill was erected around $1780-1782$ as a waterframe mill, although it was substantially rebuilt around 1827 as a steam-powered mule spinning site, whilst two late examples are known from Tameside; Albion Mill on Wednesough Green in Hollingworth built in 1794 as a four-storey brick-built mill and substantially expanded in 1859, and Gerrards Wood Mill near Gee Cross, built around 1795 as a three-storey brick mill. ${ }^{41}$

Mills containing water- and steam-powered mule spinning machines became common in the 1790s. The mules were arranged in pairs lengthwise along the mill floor facing each other, the drive shaft running between, so that one spinner (with his female and child assistants) could supervise both machines..$^{42}$ Such an arrangement required a slightly wider mill building than the Arkwright-type, as can be seen at the earliest surviving mule-spinning mill in the Manchester area. This is the originally eight-storey, steam-powered Old Mill and Decker Mill at Murray's Mill; these two spinning blocks were built by the textile entrepreneurs A. and G. Murray in Ancoats, Manchester, during the years 1798-1802, and have a combined length of $196 \mathrm{ft}(60 \mathrm{~m})$ and are $44 \mathrm{ft}(13.3 \mathrm{~m})$ wide. By the $1790 \mathrm{~s}$ and $1800 \mathrm{~s}$ most of the new cotton mills being erected were for mule-spinning since these could be more readily adapted for steam-power. For instance, the earliest surviving mule-spinning mill in Tameside was probably the steam-powered Castle Street Mill in Stalybridge, which was erected in 1805 by George Cheetham, a tenant farmer from Newton-in-Longdendale. ${ }^{43}$ With so many new textile sites being established in the 1780s and 1790s John Aikin's comment in 1795 that 'within the space of ten miles from Ashton there are near 100 mills upon this stream [the Tame] and its tributary branches' 44 comes as no surprise, and may even have been an under-estimate.

\section{Textile Finishing Sites}

The fifth, and final, type of mill structure that emerged in the 18th century was the textile finishing site. The finishing of yarn and cloth through bleaching, dyeing, and printing was common throughout the medieval and postmedieval periods, but the growing output of mechanized textile production led to a bottleneck at the finishing stage of production until two technological changes emerged to speed up the process. The first was the introduction of chemical bleaching and the second the application of steam power to the bleaching, dyeing, and printing processes which resulted in at least 67 finishing sites being established in and around Manchester during the 18th century.

Chlorine bleaching was first perfected in 1785 by the French chemist Berthollet, who demonstrated that a solution made by passing chlorine through potash had a very strong bleaching action, reducing the time taken to bleach cloth from four or five months to days and allowed the process to be moved under cover. In 1788 a Manchester chemist, Thomas 
Henry, exhibited a yard of cloth bleached in the 'new way' to a meeting of textile finishers and merchants in Manchester, already the regional centre of the textile finishing trade. This helped to popularise the process in the area, and further encouragement for its use was given in 1799 when Tennant introduced chlorine-based bleaching powder. Traditionally the cloth was treated in bundles by hand, but in 1828 David Bentley invented a washing machine that used lengths of cloth pieced or sewn together to form a near continuous process. ${ }^{45}$ However, it was not until 1845 that John Brooks, of the Sunnyside Print Works in Crawshawbooth, first used steam power to carry the ropes of cloth through all the stages of the bleaching process. This continuous process used a pulley system, and the cloth ropes were pulled through the walls separating the various bleaching and dyeing rooms via glazed bricks with large holes in them, known as pot eyes.

This newly industrialised process required large amounts of housing and storage. Consequently it led to a switch in the late 18th century from open-air bleaching grounds to an enclosed bleachworks with bleaching and dying crofts housed in long narrow one- or two-storey buildings. In Tameside the ruinous examples of late 18th-century industrial stone bleaching and dyeing tanks can still be seen at the Hodge Print works near Broadbottom in the Etherow Valley and in Bury at the Lee Hill Bleachworks near Shuttleworth in Ramsbottom. ${ }^{46}$ Later on kiers, or large free-standing vats, were used for the bleaching process, being housed in tall single-storey buildings, which still characterise many bleaching and dyeing sites today.

The introduction of new power systems at the end of the 18th and beginning of the 19th centuries (first through the waterwheel and later through the steam engine) had a big impact on the processes. Water and steam power were used to drive the singers, kiers, washing machines and drying machines that were needed to cope with the increased throughput of yarn and cloth. ${ }^{47}$ It was these steam-powered processes that enabled the Buckton Vale Bleaching and Print Works, established in 1825 , to become the largest bleaching, dyeing and calico printing works in the North-West by the end of the 19th century. ${ }^{48}$

One consequence of this development was the growth from the 1780s onwards of large clusters of bleaching, dyeing, and printing works in many of the river valleys of the region. The main areas for textile finishing were in the Ribble Valley around Accrington and Blackburn in central Lancashire, in the valleys of the Irwell, Irk, Kirklees, and Medlock around Manchester, and along the tributaries of the Mersey (the Goyt, Tame and Etherow) in north-eastern Cheshire. ${ }^{49}$ These new, extensive, industrialised landscapes were dominated by reservoirs and leat systems.

\section{The Mill Builders}

Most of the finance for the building of these 387 18th-century mills appears to have come from the tenant farms and merchants responsible for running the mills. They drew upon their own assets and those of their families and friends, the documentary evidence showing that few mill builders mortgaged lands and property other than those upon which the mill was built. ${ }^{50}$ The evidence for this can be found in three main sources for the NorthWest: insurance records from companies such as the Sun Insurance Company; land tax records for the townships in the region; and contemporary advertisements in journals such as the Manchester Mercury. In addition occasionally deeds provide evidence for the mortgage transactions which sometimes financed the construction of these mills.

Of the 387 mills identified as being built or run during the 18th century in south-east Lancashire and north-east Cheshire, 260, or approximately two-thirds, have known builders. Of these, the documentary evidence shows that 30 mill sites, or less than $12 \%$ of those with known owners/occupiers, were built by landowners. However, the work of Barnes in the early $1980 \mathrm{~s}^{51}$ indicates that the latter figure is likely to be an under-estimate since insurance records seldom mention who owned the land on which a mill was built. Likewise newspaper advertisements usually did not mention the land-owner. Many of these 30 individuals appear to have purchased this land with the expressed intention of building a mill on it and securing the water rights to that mill. Nevertheless, it is clear that the great majority of the Greater Manchester mills built in the 18th century were erected on land rented from local landowners by merchants and tenant farmers.

The way in which a tenant farming family might become involved in the capital intensive business of textile mill building can be illustrated with two families' histories from 18th-century Tameside.

The Wagstaffes first appear as farmers in Mottram township in 1692. In that year Nicholas Wagstaffe and his wife Martha built what is now known as Post Office Farm. It is a two-storey stone building with mullioned windows, coped gables and a two-storey porch in the style common in the southern Pennines at the time, on the western side of Market Street. This building was one of many new farmhouses created during the 17th and 18th centuries in the lordships of Ashton and Longdendale. The new farm holding was carved out of the neighbouring Angel Inn and Pack Horse 
Inn farms. The size of this holding was large by the standards of the time at over 30 acres. It was a compact parcel of land lying to the east of Market Street, in the area known as the Pitses. In 1727 their son John, who also described himself as a tenant farmer, held the tenancy, which was still around 30 acres. He had two sons, John born in 1752 and James born in 1758. By 1799 the family had added to this holding by renting a large portion, roughly 10 acres, of the former Ashworth tenancy, which lay immediately south of the Post Office Farm land, making it one of the largest tenancies within Mottram during this period. ${ }^{52}$

Although principally tenant farmers, they were involved in the domestic spinning of textiles during the century. During the boom of the 1780s and 1790s many of the farmers in the Mottram area took to building housing for handloom weavers. ${ }^{53}$ They and also set about converting barns or erecting new buildings to house the hand-powered spinning jennies, water-frames or mule spinning machines. In 1786 John Wagstaffe decided to convert a barn on his land into a horse or hand powered spinning jenny mill. This was on the western side of Back Lane immediately south of Old Post Office farm and was known as Wagstaffe's factory. ${ }^{54}$ Later in the 1790 s the land tax returns indicate that he had a second cotton factory opposite the first, this one being known as Dry Mill, ${ }^{55}$ though whether he ran both together is unclear. Dry Mill was erected on land opposite Wagstaffe's first factory, for a lease of 1804, mortgaging the site to Robert Newton of Heaton Norris, describes the factory as a 'new building and workshop lately erected' ${ }^{56}$ It is a stone-built two-storey building, three bays by two, with a ridge slate roof and chimneys. The west elevation has a door with a small single light to its right on the ground floor and a modern window. The first floor has a four-light flat-faced stone mullion window. The eastern elevation has three windows all with stone sills and lintels.

The precise construction date of Dry Mill is unclear. A lease of 1799 to John Ashton of Hollingworth indirectly mentions the mill, when it describes a plot of land for building a house on boarded on the northern side by the cotton factory of John Wagstaffe, on the eastern side by Mottram (Market) Street, on the western side by Back Lane and on the southern side by land belonging to Thomas Cardwell. ${ }^{57}$ Although the land tax returns do not mention the site by name until 1799, the plot of land concerned, valued at $3 \mathrm{~s} .4 \frac{1}{2} \mathrm{~d}$. can be traced in entries for 1798 and $1797 .{ }^{58}$ In 1796 the Land Tax Returns record John Wagstaffe as owning a cotton mill in Mottram, assessed at the higher rate of $3 \mathrm{~s}$. 9d., but it is possible that this referred to Wagstaffe's factory established in 1786. This suggests that Dry Mill may have been built in 1796-1797 as a replacement for Wagstaffe's factory, though it is possible that the earlier site was included in other lands owned by Wagstaffe in Mottram.

The factory did not last very long and was soon converted to cottages. This had probably occurred by 1813, for the Mottram rental of that year has no mention of the cotton factory by name, though it could have occurred as early as the remortgage in $1805 .{ }^{59}$ In this regard it is worth noting that James Wagstaffe, who is described as a shopkeeper from Mottram in three leases from the period 1792$1794,{ }^{60}$ was called a cotton spinner in a lease and re-lease dated 16 September 1806, perhaps suggesting that he had taken over Dry Mill from John Wagstaffe. ${ }^{61}$ The second family history that shows the transition from tenant farming into textile production is that of the Heap family of Moorgate Farm on the eastern edge of the township of Staley. Moorgate Farm was rented from the Stamford Estate and is an area of west-facing rough pasture over $180 \mathrm{~m}$ above sea level.

A Thomas Heape occurs in a will and inventory of 1623-1624, worth $£ 469$ 6s. 3d., describing himself as a tenant farmer. ${ }^{62}$ The inventory of his goods was modest, totalling only $£ 68 \mathrm{ls}$. $8 \mathrm{~d}$. However, he had very large sums of money owing to him, amounting to $£ 4014 s$. $7 d$. From the list of the debts owing to Thomas it is apparent that the family's main income in the early 17 th century arose from money lending to the other farmers in Mottram parish and the neighbouring parishes of Ashton, Glossop and Stockport. For instance, he had 19 kine, or cows, of which 16 were 'in keeping of', that is, rented to, 13 other farmers, mostly in Staley, but including individuals in Arnfield, Hartshead, Mottram, Mossley, and Saddleworth. Other debts owed to him came from farmers in Dukinfield, Hadfield, Heyrod, Highstone, Hollingworth, Luzley, Matley, Micklehurst, Ridge Hill, and Tunstead.

The first member of the family who can be associated with Moorgate Farm in Staley is Robert Heap. His will of 1678 states that Robert acquired Moorgate from a William Gaskell. Under the terms of Robert's will the family holdings were split in two, his eldest son Robert and his grandson, also called Robert. Each received half of Moorgate farm. A Stamford rental of 1702 records a Robert Heap tenant and a Robert Heap 'cloathmaker', possibly Robert's son, as jointly renting 17 customary acres of land at $13 \mathrm{~s}$. per annum. ${ }^{63}$ The character of the farm in the late 17 th century is indicated by the inventory of Robert Heap. This was worth $£ 13519$ s. and included 'horses, kine, sheepe, and hog' valued at $£ 51$ 16 s., 'corne and Hay' worth $£ 10$, and 'ploughes and harrows and Husbandry Geares' worth $£ 1$ $16 s .{ }^{64} \mathrm{It}$ is not clear from the inventory what if any crops were grown, though comparison 
with other Mottram parish inventories would suggest that the ploughs and harrows were used in the production of fodder crops for the farm's livestock. Robert also had debts owing to him worth $£ 4710$ s., which suggests that the family was continuing to lend to the local farmers of the parish. Joyce Powell has noted that Staley township contained the most moneylenders in the parish of Mottram whereas the highest number of borrowers lived in Godley. ${ }^{65}$ Robert had three other sons, but none of these seem to have received much from his will. The fate of such landless younger siblings who were forced to make their own way is indicated by the inventory of one of the sons, Daniel Heap, proved in 1694 when his estate was valued at only $£ 22$ 19s. ${ }^{66}$ Amongst Daniel Heap's goods and chattels were 'Cloath, yarn et wool' valued at $£ 89 \mathrm{~s}$., 'Looms, warping wools and Creeles' worth $£ 15$ s., and 'Comms and wilskits, whiles, cards and other metterals belonging to the trade', that is of a clothier, worth $14 \mathrm{~s}$. 6d. It seems that Daniel had relied heavily on textile working to compensate for the shortcomings of his small tenancy. Daniel's brother Joshua's goods were somewhat more when he died in 1708 , at $£ 3810$ s. $^{67}$

The success of this family is reflected in the surviving farm complex, much of which dates from the 18th century. The oldest element of the complex is formed by a central farmhouse, now No. 3 , dating to the 17 th century. It is two storeys in watershot stone and squared rubble, with mullion windows to both floors. The 18th-century additions include at the western end a range of two two-storey cottages again with mullion windows, which suggest that the top floor may have been used for spinning. At the eastern end there is a shippon and a barn with an arched entrance.

Robert's will of $1733^{68}$ left Moorgate to his two sons, William and Daniel, though it indicates that he was no more than a poor tenant farmer at his death with an estate worth just $£ 3$. Why the family fortunes had collapsed is unclear. Daniel's will survives from 1774, by which time the family fortunes had recovered, and although no inventory has survived internal evidence from his will suggests that the Heap family estate was worth more than $£ 68$. $^{69}$ Daniel had four sons and two daughters, and his will indicates some of the provisions frequently made for the safeguarding of such a large family. The three youngest sons received Daniel's own house in which they could live until the lease expired, whilst the eldest son, also called Daniel, received the rest of the Moorgate property, on condition that he distributed $£ 68$ amongst his relatives. ${ }^{70}$ The textile element of this family's economy appears to have become the dominant economic force. Despite inheriting the majority of the farm Daniel Heap described himself as a woollen clothier in his will of $1806 .{ }^{71}$ One of Daniel's younger brothers, Robert, appears to have set up a thriving business as a clothier and by his death in 1790 his estate was worth $£ 90 .^{72}$ Furthermore another of his younger brothers, William, took a 99-year lease on a plot of land on 1 January 1793 in the Carrbrook Valley. This was to become the first cotton spinning mill in Carrbrook, Castle Mill. It contained seven 204-spindle mule spinning machines and one with 192 spindles, four carding machines and other preparatory machinery. However, it was not mentioned in the land tax returns until 1797, suggesting that it took a few years to build. Like many of these early ventures it was not initially successful, and William had to sell the mill and its machinery in $1799 .{ }^{73}$ Both the Wagstaffe and Heap families were unable to sustain themselves for long in the new era of mechanised textile production, though other families did. One of the features of the upsurge in new mill building in the late 18 th century is the recurrence of particular family names within certain townships. In Mossley the most important textile families in the late 18th and early 19th centuries were the Andrew, Buckley, Mallalieu, and Mellor families. Elsewhere in Tameside dominant families were: in Ashton the Buckleys, Chadwicks, and Heginbottom; in Hyde the Ashtons, Hibberts, Sidebothams, and Turners; the Longdendale Valley by the Sidebottoms; and Stalybridge by the Cheethams, Harrisons, and Leeches. Most of these families would go on to dominate the economic and social history of these townships throughout the 19th century, a pattern which can be repeated in the valleys and townships around Manchester from Bolton to Saddleworth.

\section{The Chief i 8Th-Century Mill Valleys}

The impact of the 387 new mills built and operated during this century was most keenly felt in the upland valleys around Manchester. The five modern boroughs of Bury, Oldham, Rochdale, Stockport, and Tameside contain 288 early textile sites. That is $74 \%$ of all the mills built and operated in the period 1700 to 1800 within the modern county. Consequently, the upland valleys in these areas became intensively industrialised with six or more water-powered textile mills to be found along each of the valleys of the Carrbrook, Castleshaw Brook, Cheesden Brook, Kirklees Brook, Mellor Brook, Micklehurst Brook, Naden Brook, the River Spadden, and Strine Dale at the head of the Medlock.

Some of these valleys were dominated by one type of textile activity, such as textile finishing in the Kirklees Valley, wool fulling and carding along Castleshaw Brook, and cotton spinning along Mellor Brook, but the other valleys (Carrbrook, Cheesden, Mickelehurst, Naden, Spadden and Strine Dane) saw mills from a number of branches of the textile industry erected. 
The Kirklees Valley is unique in the region in being exclusively dominated by the finishing trades throughout its industrial life. By the early 19th century there were 12 textile finishing sites along a $4 \mathrm{~km}$ stretch of valley (including a small tributary), of which six were founded in the late 18th century. The first of these sites established was the Woodhill Bleach and Dye Works opened in 1786, whilst the last working site was the Kirklees Bleach Works which closed in the 1960s. Most of these sites specialised in the bleaching and dyeing of cotton yarn and cloth, although there were also three print works in the valley.

The Castleshaw Brook (also known as Hull Brook) was dominated by the woollen trade. There were eight textile sites in the valley established between 1758 (Castleshaw Mill) and 1795 (Moorcroft Wood Mill), although all bar the earliest site were established in the $1780 \mathrm{~s}$ and $1790 \mathrm{~s} .{ }^{74}$ Seven of these sites were woollen mills, two fulling mills and five scribbling mills, with a single cotton spinning mill at Hull Mill established on the brook in 1787. Three of the woollen mills were in the hands of owner-occupier textile manufacturers, which was one of the distinctive features of the 18th-century woollen industry in the southern Pennines. This intense textile activity in the valley was short-lived and by the mid-19th century all of the water-powered mills had been abandoned.

Of those valleys with a mixture of cotton, woollen, and finishing sites the most intensively industrialised was the Cheesden Valley and the associated Naden Brook. ${ }^{75}$ By the second quarter of the 19th century, 14 of the 15 textile sites in the Cheesden Valley could be found along a $5 \mathrm{~km}$ stretch of the brook, whilst its tributary the Naden Valley had eight mills along a $3.5 \mathrm{~km}$ stretch. The earliest mill to be established in these two valleys was Kershaw Bridge Mill, a dye and print works built in 1780, and water-powered textile finishing continued in the valley until the end of the 19 th century. The valley has the distinction of having the highest mill in terms of altitude anywhere in the Pennines. This was Four Acre Mill, a cotton spinning mill built around 1800 , which sat at $315 \mathrm{~m}$ above sea level. Because of the remote location of the valley it also contains some of the earliest surviving remains of cotton mills (Cheesden Lumb Higher Mill) and bleaching works anywhere in the region.

The success of the upland textile valley was short-lived and once steam power became commonly available in the 1820 s the geographical advantage of a reliable water supply became redundant, along with many of these upland mills. Those valleys that survived as industrial centres did so because the millowners were able to adapt their water-powered textile sites to the new motive power of steam.
Sometimes, this was combined with a shift to another branch of textile manufacture. From the 1850 s the industrial story of the Carrbrook Valley was one that was to be dominated by the finishing trade as represented by the Buckton Vale Print Works, the largest textile finishing site in north-west England.

\section{Notes AND REFERENCES}

1 This research was funded by Tameside Metropolitan Borough Council, one of the 10 local authorities within the county of Greater Manchester, as part of the Tameside Archaeological Survey.

${ }^{2}$ For the economy of the region in this period see Nevell, M.D., A History and Archaeology of Tameside, Volume 2: Tameside 1066-1700 (Tameside Metropolitan Borough Council with the Greater Manchester Archaeological Unit, 1991), and $A$ History and Archaeology of Tameside, Volume 3: Tameside 1700-1930 (Tameside Metropolitan Borough Council with the Greater Manchester Archaeological Unit, 1993); Nevell, M.D. and J.S.F. Walker, A History and Archaeology of Tameside, Volume 6: Lands and Lordship in Tameside. Tameside in Transition, 1348-1642 (Tameside Metropolitan Borough Council with the University of Manchester Archaeological Unit, 1998), and A History and Archaeology of Tameside, Volume 7: Transition in Tameside. The Archaeology of the Industrial Revolution in Two North-West Lordships, 1642-1870 (Tameside Metropolitan Borough Council with the University of Manchester Archaeological Unit, 1999), and Phillips, C.B. and J.H. Smith 1993, Lancashire and Cheshire from $A D 1540$ (Longman, 1993). For early linen manufacture around Manchester, see Winterbottom, D., "Sackclothes and fustyans and such like com'odyties". Early Linen Manufacture in the Manchester Region', in Roberts, E. (ed.), A History of Linen in the North West (Centre for North West Regional Studies, University of Lancaster, 1998).

3 Powell, J., 'The Parish of Mottram-inLongdendale, 1570-1680' (unpublished Local History Certificate dissertation, University of Manchester Dept of Extra Mural Studies, 1976), 27 - copy in the Tameside Local Studies Library. Other notable works transcribing the 17th-century wills and inventories from the parishes around Manchester include Petford, A.J. and P.M. Buckley, Saddleworth Wills and Inventories 1649-1679 (Saddleworth: WEA, 2003); King, D., A Study of the Probate Records for the Parishioners of Ashton-under-Lyne 1660-1680 (Manchester: University of Manchester Extra-Mural Department, 1987); Phillips, C.B. and J.H. Smith (eds), Stockport Probate Records 1578-1619 (Record Society of Lancashire and Cheshire CXXIV, 1985), and Stockport Probate Records 1620-1650 (Record Society of Lancashire and Cheshire, CXXXI, 1992). Groves, J., Piggins Husslements and Desperate Debts. A Social History of North-east Cheshire through Wills and Probate Inventories, 1600-1760 (Northern Writers Advisory Service, 1994) also contains much useful information and a good deal of the primary data used in this study has since been published in detail. Wadsworth and Mann's 1931 classic study of the early cotton industry in the North-West also contains much information regarding references to the early use of cotton in probate evidence around Manchester; Wadsworth, A.P. and J. Mann, The Cotton Trade and Industrial Lancashire (Manchester: University of Manchester, 1931).

${ }^{4}$ Stobart, J., The First Industrial Region. North-west England, c.1700-60 (Manchester: Manchester University Press, 2004), 42-6.

5 Nevell, M., 'Bury, The Archaeology of Pennine Valley' (unpublished report by UMAU, 1999); Powell, ref. 3. 
${ }^{6}$ This cottage was built as a dual house and woollen workshop around 1742 and extended around 1800 John Smith, W., Saddleworth Buildings. A Guide to the Vernacular Architecture of the Parish of Saddleworth in the Pennines (Saddleworth: Saddleworth Historical Society in association with the Saddleworth Festival of Arts, 1987), 88-9.

UMAU, 'South View, Cheadle. Interim Report on the study of the development of an $18^{\text {th }}$ and $19^{\text {th }}$ century range of vernacular buildings' (unpublished client report, UMAU, 1999).

8 Palmer, M., 'The Workshop: Type of Building or Method of Work?' in Barnwell, P.S., M. Palmer and M. Airs (eds), The Vernacular Workshop: from Craft to Industry, 1400-1900 (Council for British Archaeology Research Report Series 140, York, 2005), 2. Wadsworth and Mann described these artisans as 'country manufacturers' (Wadsworth and Mann, ref. 3, 78-96).

9 Palmer, ref. 8, 7. Wadsworth and Mann described these merchant capitalists as the 'Manchester merchants', since Manchester was usually their operational base.

10 Several of these Manchester properties were surveyed in detail by the Manchester Early Dwellings Research Group in the 1980s and more recently by the University of Manchester Archaeology Unit with the Manchester region Industrial Archaeology Society (Nevell 2003, 36-7). The standard works on Lancashire's weavers' cottages remain Geoff Timmins' two classic surveys of examples from the Ribble Valley, where the two-storey weaver's domestic workshop was the norm; Timmins, G., Handloom Weavers Cottages in Central Lancashire (Lancaster: University of Lancaster, 1977), and 'Handloom Weavers' Cottages in Central Lancashire: Some Problems of Recognition', Post-Medieval Archaeology (1979), 251-72.

${ }_{11}$ Nevell and Walker, ref. 2, 84, recorded 63 extant examples but continued survey work by the Tameside Archaeological Survey, run by UMAU on behalf of Tameside $\mathrm{MBC}$, has raised this number to 77 examples.

12 Nevell and Walker, ref. 2, 1999, 68-70; in the 18th and early 19th centuries the Heap family lived at Moorgate Farm, the Wrigley family at Wrigley Fold and the Shaw family at The Fold. All were involved in domestic textile production as an adjunct to their farming income. See for instance Chester and Cheshire Record Office (CRO) Wills and Inventories; Daniel Heap of Moorgate, Staley, clothier, 1806; Joshua Wrigley of Matley, Clothier, 1814. Wrigley Fold has two datestones which read 'IWA 1738' and 'IWA 1707' and probably refer to a Joshua Wrigley (Joshua being a preferred name in the family).

${ }_{13}$ Burke, T. and M. Nevell, A History and Archaeology of Tameside, Volume 5: Buildings of Tameside (Tameside Metropolitan Borough with the University of Manchester Archaeological Unit, 1996), 56-8; CRO, DTW 2477/F12.

${ }_{14}$ CRO, Land Tax Returns for Dukinfield (QDV2/ 148), Godley (QDV2/174), Hattersley (QDV2/204) Hollingworth (QDV2/217), Hyde (QDV2/231), Matley (QDV2/285), Newton (QDV2/313), Stayley (QDV2/393, Tintwistle (Micklehurst division QDV2/ 427), and Werneth (QDV2/499), 1780 to 1831.

${ }_{15}$ Palmer, M. and P. Neaverson, Industrial Archaeology. Principles and Practices (Routledge, 1998), 79-81.

16 Williams, M. with D. Farnie, Cotton Mills in Greater Manchester (Lancaster: Carnegie Publishing Ltd, 1992).

${ }_{17}$ Chapman, S.D., 'The Arkwright Mill Colquhoun's Census of 1788 and Archaeology Evidence', Industrial Archaeology Review VI.1 (1982), 19-22.

18 Aspin, C., The Water Spinners (Helmshore: Helmshore Local History Society, 2003); Calladine, A. and J. Fricker, East Cheshire Textile Mills (Royal
Commission on the Historical Monuments of England, 1993); Nevell, M., 'From Linen Weaver to Cotton Manufacturer: Manchester During the $17^{\text {th }}$ and $18^{\text {th }}$ Centuries and the Social Archaeology of Industrialisation', in Nevell, M. (ed.), From Farmer to Factory Owner. Models, Methodology and Industrialisation. The Archaeology of the Industrial Revolution in North West England (Council for British Archaeology North West Archaeology North-West Volume 16, 2003), 41.

19 Wadsworth, A., 'The History of the Rochdale Woollen Trade', Transactions of the Rochdale Literary and Scientific Society, 15 (1923-1925), 90110.

20 Jones, W., Dictionary of Industrial Archaeology (Stroud: Sutton Publishing Limited, 1996), 326-7.

${ }^{21}$ Ibid., 57.

22 Aspin, C., The Cotton Industry (Princes Risborough: Shire Album No. 63, Shire Publications Ltd, 1981), 5-6; Benson, A.P., Textile Machines (Princes Risborough: Shire Album No 103, Shire Publications Ltd, 1983), 10.

${ }_{23}$ McNeil, R. and M. Nevell, A Guide to the Industrial Archaeology of Greater Manchester (Association for Industrial Archaeology, 2000), 31; Smith, W.J., Saddleworth Buildings. A Guide to the Vernacular Architecture of the Parish of Saddleworth in the Pennines (Saddleworth: Saddleworth Historical Society, 1987), 129.

${ }_{24}$ Calladine and Fricker, ref. 18, 24-5.

25 Ibid., 22-5, 29-30; Arrowsmith, P., Stockport, A History (Stockport Metropolitan Borough Council with the University of Manchester Archaeological Unit, 1997), 97-101.

26 Benson, ref. 22, 12.

27 Jones, ref. 20, 249-50.

28 Benson, ref. 22, 15.

29 Aspin, ref. 22, 12; Benson, ref. 22, 13-14.

30 Benson, ref. 22, 15.

31 Jones, ref. 20, 249.

${ }^{32}$ Haynes, I., Cotton in Ashton (Tameside: Libraries and Arts Committee, Tameside Metropolitan Borough, 1987), 10; Nevell, M.D., A History and Archaeology of Tameside, Volume 4: The People Who Made Tameside (Tameside: Tameside Metropolitan Borough Council with the University of Manchester Archaeological Unit, 1994), 172; Nevell and Walker, ref. 2, 1999, 52-3.

33 Haynes, I., Stalybridge Cotton Mills (Manchester: Neil Richardson publications, 1990), 16-18.

${ }_{34}$ Haynes, ref. 32, 17; Nevell, ref. 2, 1993, 60-1.

35 Butterworth, E., An Historical Account of the Towns of Ashton-under-Lyne, Stalybridge and Dukinfield (Ashton-under-Lyne, 1842), 82.

${ }^{36}$ CRO, DTW 2477/B/10; Nevell, ref. 2, 1993, 60-1.

${ }^{37}$ CRO, DTW 2477/F/12; Nevell, ref. 2, 1993, $60-1$.

38 Aspin, ref. 18, 8, 26-7.

39 Chapman, ref. 17, 10, 16.

40 Manchester Mercury, 26 August 1788.

${ }^{41}$ Aspin, ref. 18, 452; Nevell and Walker, ref. 2, 1999, 14

42 Jones, ref. 20, 250.

${ }^{43}$ Haynes, ref. 33, 27; Nevell and Walker, ref. 2, 1999, 46.

44 Aikin, J., A Description of the Country from Thirty to Forty Miles Round Manchester (John Stockdale, 1795), 227.

45 Aspin, ref. 22, 25.

46 McNeil and Nevell, ref. 23, 56; Ashmore, O., The Industrial Archaeology of North-West England (Manchester: Manchester University Press, 1982), 220.

47 Ashmore, ref. 46, 5.

48 Nevell, M. with B. Grimsditch and C. King, The Archaeology of Tameside Volume 6: Carrbrook. A Textile Village and its Valley. A Study in the 
Industrialisation of the Pennine Uplands (Tameside: Tameside Metropolitan Borough Council with the University of Manchester Archaeological Unit, 2006), 53.

49 Ashmore, ref. 46, McNeil and Nevell, ref. 23.

50 Aspin, ref. 18; Barnes, B., 'Early Woollen Mills in a Pennine Parish: Saddleworth and the Upper Tame Valley', Saddleworth Historical Society Bulletin, 13.2 (1983), 31.

51 Barnes, ref. 50, 31-3.

52 CRO, DTW 2477/B/10

53 Nevell and Walker, ref. 2, 1998, 70-6.

${ }^{54}$ CRO, DTW 2477/B/10.

55 CRO, QDV2/299.

${ }^{56}$ CRO, EDT 281

57 CRO, DTW 2477 F/12.

${ }^{58} \mathrm{CRO}, \mathrm{QDV} 2 / 299$

59 CRO, DTW 2477/B/12.
${ }^{60}$ CRO, D 3553/19-21.

${ }_{61}$ CRO, D 3553/24.

${ }^{62}$ CRO, WS Heap 1623-4.

63 John Rylands Library, Dunham Massey MSS, Accession 8/5/92 Box 4/1.

${ }^{64}$ CRO, WS Heap 1678.

65 Powell, ref. 3, 15-16, 24-5.

${ }^{66}$ CRO, WI Heap 1694.

${ }^{67}$ CRO, WS Heap 1708.

${ }^{68}$ CRO, WI Heap 1733.

${ }^{69}$ CRO, WS Heap 1774.

${ }^{70}$ CRO, WS Heap 1774.

71 CRO, QDV2/393; CRO WS.

72 CRO, WS Heap 1790.

${ }^{73}$ Haynes, I., Mossley Textile Mills (Manchester: N. Richardson, 1996), 6-7, 36.

${ }^{74}$ Redhead 2003, 69-71.

75 Ashmore, ref. 46, 1969.

Dr Michael Nevell is Director of the University of Manchester Archaeology Unit. Address for correspondence: School of Arts, Histories and Cultures, University of Manchester, Oxford Road, Manchester M13 9PL, UK. He delivered the Rolt lecture in 2005. 